\title{
Gap between Perception and Behavior of Men about the Sexual and Reproductive Rights of Women in India
}

\begin{abstract}
Ankita Siddhanta ${ }^{1}$ and S.K. Singh ${ }^{1}$
This paper explores the gap between the perception and actual behaviour of Indian men towards the sexual and reproductive rights of women in the country. Data from National Family Health Survey (NFHS, 2005-2006) and from Coordinated HIVIAIDS Response through Capacity Building and Awareness (CHARCA, 2007-2008) was used. Results revealed a considerable gap in men's perception and behaviour. The gap is almost double in the state of Bihar compared with national average. It (the gap) is more conspicuous in districts than their respective states. Positive communication to address power dynamics within marriage is vital and needs to be promoted to tackle this issue.
\end{abstract}

Keywords: perception, behavior, gap, sexual reproductive rights of women, India

\footnotetext{
${ }^{1}$ International Institute for Population Sciences, India. Email: ankita.siddhanta@gmail.com
} 


\section{Introduction}

How much do the various programmes and researches on reproductive and sexual health help to defend the sexual and reproductive rights of women? The recent atrocities in India have proved that women are still not safe be it due to feticide or rape; incidents which can only be referred to as a violation of women's sexual and reproductive rights. The corollary of these barbarous acts ranges from various physical and mental adversities.

According to National Crime Records Bureau (2015), a total of 327,394 cases of crime against women were reported in India, a decline of 3.1 percent from 2014. These crimes have continuously increased during 2011 - 2014 with 228,650 cases in 2011 and 337,922 cases in 2014. A total of 34,651 cases of rape under section 376 IPC were registered during 2015 (excluding cases under the Protection of Children from Sexual Offences Act, 2012). An increasing trend in the incidence of rape has been observed during 2011 - 2014. These cases have shown an increase of 9.2 percent in the year 2011 (24,206 cases) over the year 2010 (22,172 cases), and continued to increase to 36,735 cases in 2014 . A decrease of 5.7 percent was reported in 2015 (34,651 cases) over 2014 (36,735 cases). Kidnappings and abduction of women have increased by 3.4 percent in 2015 than 2014. Though dowry deaths of women have declined by 10 percent in 2015, but the number (7,634 cases) is still high enough to be a concern.

Between the years of 2001 and 2011, the number of crimes against women has risen an alarming 59 percent, and the leading crime was rape (John 2013). Though critics question whether figures reflect an upsurge in crime or an upsurge in crime reporting, evidence of institutional and cultural gender injustice remains unarguable (Livne, 2015). Latest data from NFHS-4 fact sheets reveal that although lesser women than NFHS-3 have experienced spousal violence, still the percentage is as high as 29 percent (2015-2016). 20 percent of Indian men admit to forcing their wives or partners to have sex (Barker, Contreras, Heilman, Singh, Verma \& Nascimento, 2011). Out of 34,651 rape cases, in 33,098 cases the offenders were known to the victims accounting for 95.5 percent of total rape cases (NCRB, 2015). Looking at the shocking data on violence against women, it can be assumed that women in India are at high risk and the risk even sometimes pertains within the family. 
Last two decades witnessed enormous attempts to include the concept of sexual and reproductive health and wellbeing in the arena of human rights. Though this conceptualization of sexual and reproductive rights has been achieved with a fair measure of success, the privileges is yet to be experienced by women in many circumstances.

Respect for bodily integrity was recognized as a fundamental element of human dignity and freedom as early as 1975 at the World Conference of the International Women's Year in Mexico City. It was further defined and elaborated in the Beijing Platform for Action. While sexual rights were not specifically defined either by ICPD or by the Fourth World Conference on Women in Beijing in 1995, or at their fiveyear follow-up conferences, ICPD did elaborate on reproductive rights. It was also felt that language and cultures affect the perception of terms such as 'sex'.

Any act involving violation of bodily rights of women is likely to result in physical, psychological and sexual injury. It not only takes away their liberty and freedom but also curbs their decision-making power on the matter of their body. There always remains a significant association between coerced sex and a range of negative health and reproductive health outcomes for women in the reproductive age group. The gynecological problems associated with sexual abuse are chronic pelvic pain, urinary tract infection, vaginal bleeding, painful intercourse, and pelvic inflammatory diseases. Adverse sexual and reproductive health outcomes are more likely to be experienced by women who have experienced forced and coercive sex (Jejeebhoy \& Bott, 2006). Women experiencing violence are more likely to report gynecological morbidity, pelvic inflammatory diseases and pelvic pain (Heise, Ellsberg \& Goettemoeller, 1999; Stephenson, Koenig \& Ahmed, 2006). A study in two metro cities in India found that the outcome of coercive and forced sex as reported by women were gynaecological disorders, sexually transmitted infections and unintended pregnancy followed by unsafe abortions (Gupta \& Ailawadi, 2005). The consequences of gender-based violence include severe short- and long-term damage on women's health and significant health risks for their children (Renate, 2004). Stark and Flitcraft (1996) have identified "battered woman syndrome" characterized by recurrent assaultive injuries, stress-related injuries, isolation, substance abuse and mental illness among women who have experienced domestic violence. The consequences of gender-based violence are devastating including life-long emotional distress, mental health problems such as posttraumatic stress disorder and poor reproductive health outcomes. Common mental health problems experienced by abused women include depression, anxiety, posttraumatic stress, insomnia, and harmful use of alcohol, as well as a range of somatic and psychological complaints 
(Gomel, 1997). From a cross sectional study in India, Chowdhury and Patel (2008) found an association between violence and a range of self-reported gynecological complaints, low body mass index, depressive disorder, and suicide attempts.

The emergence of a patriarchal hierarchy can be traced from the Pre Vedic Period to post-independence India (Livne, 2015). Startling figures from the NCRB (National Crime Research Bureau) clearly exhibit gender inequality running deep in our society (Chadda, 2016). Miller (1993) where women are assigned to a subordinate status to men.

Against this backdrop, this study aimed to explore the gap between the perception and the behavior of men towards the bodily rights of women.

\section{Data and Methods}

The data sources used for this study were NFHS- 3 National Family Health Survey (2005-2006) and CHARCA- Coordinated HIV/AIDS Response through Capacity Building and Awareness (2007-2008 End Line Study Report).

NFHS-3 is a national representative large scale survey covering more than 124,385 women aged 15-49 and 74,369 men aged 15-54 from 109,041 households selected by multistage probability sampling approach. It was conducted in all 29 states of India by the International Institute for Population Sciences (IIPS). The Macro International CHARCA study provided a micro level perspective in the reproductive and sexual rights of young people across 5 districts (Aizwal, Bellary, Guntur, Kanpur and Kishenganj) providing varying cultural contexts in reproductive and sexual rights. The CHARCA survey was conducted by International Institute for Population Sciences, India. Four states (NFHS-3) and four districts (CHARCA 2008) were chosen for the present study. The study areas are shown in Figure 1. 
Figure 1: Study Areas

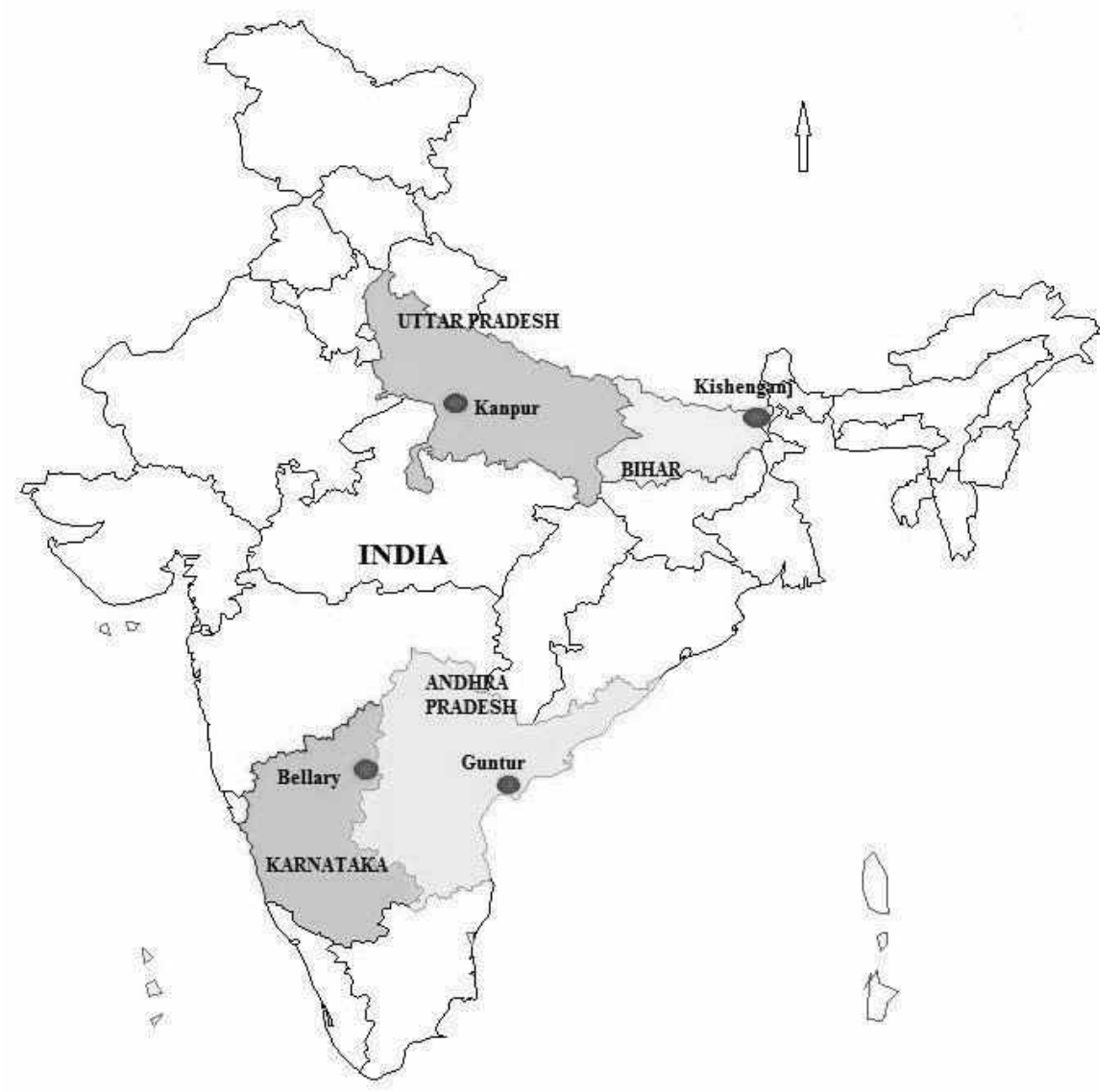

\section{Rationale Behind Choosing the Selected States and Districts}

The study was based on one district from each of four states namely, Bellary in Karnataka (known for the prevalence of Devadasi system, where the eldest daughter of a family is offered to the priest), Guntur in Andhra Pradesh (an area where proportion of mobile sex workers has been increasing and extramarital sex has no longer been a taboo), Kanpur in Uttar Pradesh (where dominance of single male migration has been creating a conducive environment for women's vulnerability to HIV/AIDS even in spite of very traditional society having strong patriarchal norms), Kishanganj, Bihar (the bordering district connecting Nepal and Bangladesh and internationally known route for trafficking of women for the sex trade in India from neighbouring countries). Accordingly, the states of Bihar, Karnataka, Andhra 
Pradesh and Uttar Pradesh were chosen for analysis. To get a macro perspective on the reproductive and sexual rights of women in India, whole India level data was also analysed.

The major dependent variables utilized in this study consists of (1) experience of sexual violence by women (NFHS), (2) the right of husband to force wife for sex when she is unwilling (NFHS), (3) women unwillingness to have sex when not wanted (CHARCA), (4) experience of forcing wife for sex (CHARCA), and (5) reaction of husband when a woman say's no to sexual intercourse (CHARCA).

The independent variables used in this study are (1) woman's age (15-19 years; 20 34 years; $35-39$ years), (2) wife's age (less than 25 years; $25-40$ years; 40 and above years), (3) husband's age (less than 25 years; $25-40$ years; 40 and above years); (4) marital status of the women (currently not married; currently married) (5) place of residence (urban; rural), (6) social status (scheduled caste - SC; scheduled tribe- ST; other backward caste - OBC; others), (7) religion (Hindu; Muslim; Christian; others), (8) wealth quintile (poorest; poor; middle; richer; richest), (9) wife's education (no education; primary; secondary; higher), (10) husband's education (no education; primary; secondary; higher), (11) wife's exposure to mass media (yes; no), (12) husband's exposure to mass media (yes; no) and (13) husband's alcohol drinking (yes; no), (14) woman heard about STI (yes; no), (15) woman heard about HIV/AIDS (yes; no), woman drinks alcohol (yes; no), number of lifetime sexual partners of woman (1;2 or 3; more than 3), woman's age at first intercourse (did not have intercourse; less than 18 years; 19 and above years); woman's intensity of gender role (disagree to all wife beating variables; agrees to at least one; agrees to all).

The gap between the perception and behaviour of Indian husbands was ascertained using a bivariate analysis i.e. cross tabulations of the variable-perception of the men and variable- experience of sexual violence by their wives. Chi squared test was applied to assess the association of the 'gap' with other background characteristics.

Indian married men (husbands) were categorized into two groups: (1) men with a "negative perception" and (2) men with "positive perception" about the bodily rights of women. Each of the two groups were further categorised on the basis of their behaviour related to intercourse or other sexual acts with their wife into 4 sub-groupsthe positive concordance group; the positive disconcordance group; negative disconcordance group; and negative concordance group (Figure 2). The positive concordance group comprised married men who perceived sexual and reproductive rights of women positively and did not force their wife to have intercourse or other 
sexual acts and thus do not violate the rights of their wife. The positive disconcordance group comprised those married men who, although perceive positively about the bodily rights of women, yet they force their wife for intercourse or other sexual acts and thus violate her rights. The negative disconcordance group comprised those married men who although perceive negatively about the bodily rights of women, yet they do not force their wife for intercourse and other sexual without her consent or will. Finally, negative concordance group comprised those married men who perceive negatively about the bodily rights of women and they also force their wife for intercourse or other sexual acts without her will or consent. Based on the above categorization we calculated the positive and negative gaps in the perception and behaviour of married men in India. The gap in the perception and behaviour was considered as 'positive gap' if despite perceiving negatively about the bodily rights of women, a married man did not force his wife for intercourse or other sexual acts without her consent or will. On the other hand, the gap was termed as 'negative gap' if despite perceiving positively about the bodily rights of women, a husband forced his wife for intercourse or other sexual acts without her will or consent. In the present study, the focus was made on the 'negative gap' between perception and behaviour of the men. 
Figure 2: Groups of Men Showing Concordance and Disconcordance between Their Perception and Behaviour (India)

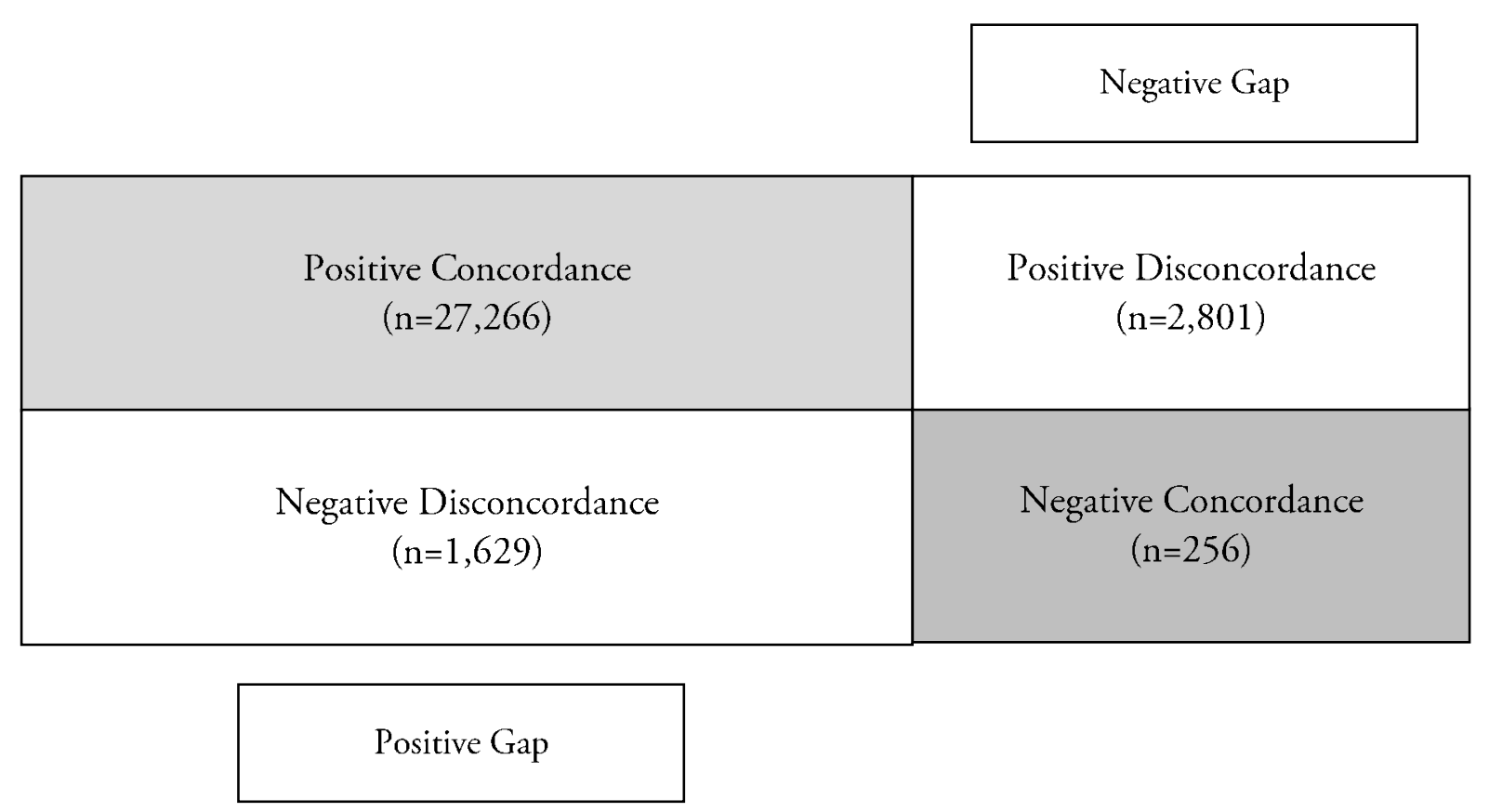

\section{Results}

\section{Experience of Sexual Violence among Ever Married Women}

Table 1 reveals that the prevalence of sexual violence among ever married women in India was 10 percent, with the southern states experiencing less sexual violence. Highest prevalence of sexual violence among ever married women was found in Bihar (20 percent) compared to only 4 percent in Andhra Pradesh and Karnataka. According to Table 2, women of the age group 20-35 experienced more sexual violence. With increasing number of lifetime sexual partners among the women, experience of sexual violence also increased. Women who had their first sexual intercourse below the age 18 faced greater exposure to sexual violence than those who initiated sexual intercourse at the age of 19-29 years.

Education and wealth quintile had an inverse relationship, thus sexual violence among ever married women was most prevalent in the poorest wealth quintile, to decrease significantly in the richest wealth quintile. Only 1 percent women in the richest wealth quintile of Karnataka faced sexual violence. Experience of sexual 
violence was less among highly educated women compared to women who were not educated. In India, 13 percent of women who were not educated experienced sexual violence as compared to only 2 percent of women from highly educated category. Women from non-scheduled caste (SC), scheduled tribe (ST) or non-other backward class $(\mathrm{OBC})$ caste in India experienced less sexual violence than women of SC, ST or OBC. There was lesser chance of experience of sexual violence among women who were exposed to mass media and the opposite was true for women who drank alcohol. Those women who had heard about HIV/AIDS faced less sexual violence. Around 13 percent of women in India who were not exposed to mass media, experienced sexual violence perpetrated by their husband compared to 9 percent who were exposed to mass media. Women justifying acts of wife beating faced more sexual violence than those women who did not justify the practice, except in Andhra Pradesh.

Working women faced more sexual violence than their non-working counterparts. More than one-tenth working women experienced sexual violence compared to those who were not working. In Karnataka 6 percent working women faced sexual violence compared to only 2 percent women from the non-working group. In India women whose husbands were alcoholic were also more prone to sexual violence.

The situation for forced sex changes slightly when district level data of CHARCA study was analysed (Table 1). Proportion of women who have experienced forced sex was highest in Kanpur (67.8 percent) and lowest in Guntur ( 40 percent). In the other districts, half of the women had experienced forced sex, again showing a demeaning scenario. The study revealed a lack of control over their own sexuality among the women in the districts.

Table 1: Ever Married Women's Experience of Sexual Violence in Selected Districts and States of India

\begin{tabular}{ccccc}
\hline \multicolumn{5}{c}{ Percentage of ever married women who experienced Forced sex } \\
\hline Experience & Kishenganj & Kanpur & Bellary & Guntur \\
& $(259)$ & $(320)$ & $(268)$ & $(285)$ \\
\hline India & 48.9 & 67.8 & 50.5 & 40 \\
$(72677)$ & Bihar & Uttar Pradesh & Karnataka & Andhra Pradesh \\
& $(5394)$ & $(10199)$ & $(4363)$ & $(6248)$ \\
\hline 10 & 20 & 9.4 & 3.9 & 4.1 \\
\hline
\end{tabular}

Figures in brackets indicate Number (n) 
Table 2: Ever Married Women's Experience of Sexual Violence, by Selected Background Characteristics in India and Selected States

\begin{tabular}{|c|c|c|c|c|c|}
\hline $\begin{array}{l}\text { Women's Background } \\
\text { Characteristics }\end{array}$ & India & $\begin{array}{l}\text { Uttar } \\
\text { Pradesh }\end{array}$ & Bihar & Karnataka & $\begin{array}{l}\text { Andhra } \\
\text { Pradesh }\end{array}$ \\
\hline \multicolumn{6}{|l|}{ Women's Age } \\
\hline $15-19$ & 13 & 9.4 & 18.4 & + & 3.2 \\
\hline $20-35$ & 10.4 & 10.1 & 21.2 & 3.9 & 4.7 \\
\hline $35-49$ & 8.8 & 8.2 & 18.4 & 4.3 & 3.4 \\
\hline \multicolumn{6}{|l|}{ Place of Residence } \\
\hline Urban & 7.1 & 8.4 & 23.2 & 3.2 & 4.4 \\
\hline Rural & 11.2 & 9.8 & 19.5 & 4.4 & 4 \\
\hline \multicolumn{6}{|l|}{ Social Status } \\
\hline SC & 13 & 11.7 & 28.0 & 5.3 & 6.3 \\
\hline ST & 11.3 & 9.6 & + & 4.0 & 7.4 \\
\hline $\mathrm{OBC}$ & 8.5 & 9.4 & 18.6 & 3.4 & 3.3 \\
\hline Others & 8.8 & 7 & 16.8 & 3.9 & 3.4 \\
\hline Don't know & & & 8.7 & & \\
\hline \multicolumn{6}{|l|}{ Religion } \\
\hline Hindu & 9.7 & 9.7 & 20 & 4 & 3.7 \\
\hline Muslim & 73.5 & 8.5 & 20.3 & 2.3 & 7.8 \\
\hline Christian & 5.7 & 0 & No value & 7 & 4.2 \\
\hline Others & 5.6 & 0 & 0 & + & 0 \\
\hline \multicolumn{6}{|l|}{ Wealth Quintile } \\
\hline Poorest & 14.6 & 11.3 & 23.4 & 6.2 & 3.3 \\
\hline Poor & 12.7 & 10 & 20.1 & 5.4 & 5.2 \\
\hline Middle & 10.2 & 10.2 & 20 & 4.7 & 4.7 \\
\hline Richer & 7.8 & 8 & 16.6 & 3 & 4.5 \\
\hline Richest & 4 & 5 & 11.2 & 1.1 & 1.7 \\
\hline \multicolumn{6}{|l|}{ Education } \\
\hline No education & 12.5 & 10.4 & 21.9 & 5.2 & 4.5 \\
\hline Primary & 11.1 & 9.7 & 22.9 & 4.1 & 4.5 \\
\hline Secondary & 6.8 & 8 & 12.5 & 3.1 & 3.5 \\
\hline Higher & 2.1 & 1.3 & 4.2 & + & + \\
\hline \multicolumn{6}{|l|}{ Marital Status } \\
\hline Currently not married & 12.9 & 14.8 & 17.5 & 13.2 & 11.4 \\
\hline Currently Married & 8.3 & 9.2 & 20.1 & 3.2 & 3.5 \\
\hline \multicolumn{6}{|l|}{ Heard about STI } \\
\hline Yes & 14.2 & 8.2 & 17.4 & 3.8 & 4.4 \\
\hline No & 9.7 & 10.5 & 23.5 & 4.2 & 3.2 \\
\hline \multicolumn{6}{|c|}{ Heard about HIV/AIDS } \\
\hline Yes & 7.5 & 7.7 & 18.3 & 3.7 & 4.4 \\
\hline No & 13.3 & 10.4 & 20.9 & 4.3 & 3.2 \\
\hline \multicolumn{6}{|c|}{ Exposed to Mass Media } \\
\hline Yes & 8.7 & 9.1 & 18.5 & 3.9 & 3.8 \\
\hline & & 274 & & & \\
\hline
\end{tabular}




\begin{tabular}{|c|c|c|c|c|c|}
\hline $\begin{array}{l}\text { Women's Background } \\
\text { Characteristics }\end{array}$ & India & $\begin{array}{c}\text { Uttar } \\
\text { Pradesh }\end{array}$ & Bihar & Karnataka & $\begin{array}{l}\text { Andhra } \\
\text { Pradesh }\end{array}$ \\
\hline No & 13.3 & 10.1 & 21.7 & 4.3 & 5.5 \\
\hline \multicolumn{6}{|l|}{ Drinks Alcohol } \\
\hline Yes & 15.2 & 25 & 44.1 & 9.1 & 5.1 \\
\hline No & 9.8 & 9.4 & 19.7 & 3.9 & 4 \\
\hline \multicolumn{6}{|c|}{ Number of Lifetime Sexual Partners } \\
\hline 1 & 9.8 & 9.3 & 19.7 & 3.9 & 3.9 \\
\hline 2 or 3 & 19.6 & 20.4 & 41.4 & 10 & 20.7 \\
\hline More than 3 & 11.8 & 0 & + & + & 11.8 \\
\hline \multicolumn{6}{|l|}{ Age at First Intercourse } \\
\hline Did not have & 12 & 10.1 & 21.6 & 4.7 & 4.6 \\
\hline \multicolumn{6}{|l|}{ intercourse } \\
\hline Less than 18 & 6.9 & 8.2 & 14.1 & 2.8 & 3.1 \\
\hline 19 and above & 10.1 & 10 & 21.7 & 6 & 0 \\
\hline \multicolumn{6}{|c|}{ Intensity of Gender Role } \\
\hline $\begin{array}{l}\text { Disagree to all wife } \\
\text { beating variables }\end{array}$ & 8.9 & 7.6 & 17.9 & 3.2 & 2.8 \\
\hline Agrees to at least one & 10.6 & 9.1 & 21.4 & 3.8 & 6.6 \\
\hline Agrees to all & 11 & 12.9 & 21.7 & 6.1 & 3.5 \\
\hline Number (n) & 72677 & 10199 & 5384 & 4262 & 6248 \\
\hline
\end{tabular}

\section{Husband's Behavior when their Wife Refuses to Have Sex in the Selected Districts}

Over 50 percent of husbands in the districts respected their wife's decision when she was unwilling to have sex, except in Kanpur (38 percent) where more than half of the men blackmailed or forced their wives for sex when she was unwilling (Table 3). The instance of 'beating wife but not having sex' when wife was unwilling was not uncommon in the districts that were studied. 
Table 3: Husband's Reaction to Woman's Unwillingness to Sex among Currently Married Women in the Selected Districts of India

\begin{tabular}{lrrrr}
\hline Reaction & Kishenganj & Kanpur & Bellary & Guntur \\
\hline Respects decision & 52.6 & 37.5 & 53.67 & 54.49 \\
Blackmails/forces & 32.8 & 56.25 & 34.36 & 36.77 \\
Beats but does not have sex & 7.7 & 3.13 & 8.11 & 5.09 \\
Goes to other women & 3.2 & 0 & 2.7 & 1.77 \\
others & 3.6 & 3.13 & 1.16 & 1.88 \\
$\mathrm{~N}$ & 247 & 160 & 259 & 235 \\
\hline
\end{tabular}

\section{Gap between Perception and Behavior in India and Selected States}

According to NFHS 3 (2005-2006), Indian men kept a positive perception and attitude towards the bodily rights of women, though the perception became little less positive on their reproductive rights. In India, most men did not agree to wife beating and had the view that wives could refuse sex. This perception is common for men who were married and played the role of husband.

Despite the Indian men's positive perception, approximately 10 percent of Indian women experienced sexual violence within marriage. Thus it is necessary to explore the sexual behaviour of the men who perceived positively about their wives' bodily rights by looking at the sexual experience of their wives. It was evident that nearly one in ten men in India portrayed gap in his perception and behavior (positive disconcordance group) which further increased to 17-18 percent in Bihar (Table 4). The gap between perception and behavior was the lowest in Karnataka (2.6 percent) and Andhra Pradesh (3.1 percent) implying that the men in these states behaved in the way guided by their positive perception. Thus results confirmed the study hypothesis that "there is no gap between the perception and the behavior of men about women's sexual rights and reproductive rights in India" was rejected and the alternative hypothesis "there is a considerable gap between the perception and the behavior of men about women's sexual rights and reproductive rights in India” accepted. 
Table 4: Percentage of Married Men Showing Gap between Perception and Behavior in India and Selected States

\begin{tabular}{lc}
\hline Selected States & Gap \\
\hline India & 8.8 \\
Andhra Pradesh & 3.1 \\
Karnataka & 2.6 \\
Bihar & 17.6 \\
Uttar Pradesh & 8.5 \\
\hline
\end{tabular}

The Chi-square tests of selected background characteristics (Table 5) suggested that both husband and wives' age, place of residence, social status, religion, wealth quintile, education, mass media exposure, husband's alcoholism, were significantly associated with the gap between the perception and behavior of husbands. The gap was found to be larger where wives are below 25 years of age. Except in Bihar, rural areas showed larger gaps between perception and behavior in comparison with urban areas. Wife's age and religion were not associated with the gap among married males in Bihar and Uttar Pradesh who reported that husbands were not justified in forcing wives to unwilling sex. The gap between perception and behavior was found to be greater for Muslim, SC, poor, men with no education and no exposure to the media. Uneducated women's husbands had more chances to show a gap between their perception and behavior. About 30 percent of men from the SC category in Bihar had forced sex even though they had a positive notion about the sexual rights of their wives. 
Table 5: Gap between Perception and Behavior of Married Men who Reported that Husbands are not Justified in Forcing Wives for Sex when She is Unwilling, by Some Selected Background Characteristics in India and Selected States

\begin{tabular}{|c|c|c|c|c|c|c|c|c|c|c|}
\hline $\begin{array}{l}\text { Background } \\
\text { characteristics }\end{array}$ & India & $\begin{array}{c}\text { Chi } \\
\text { Square }\end{array}$ & Bihar & $\begin{array}{c}\text { Chi } \\
\text { Square }\end{array}$ & $\begin{array}{c}\text { Uttar } \\
\text { Pradesh }\end{array}$ & $\begin{array}{c}\text { Chi } \\
\text { Square }\end{array}$ & Karnataka & $\begin{array}{c}\text { Chi } \\
\text { Square }\end{array}$ & $\begin{array}{l}\text { Andhra } \\
\text { Pradesh }\end{array}$ & $\begin{array}{l}\text { Chi } \\
\text { Square }\end{array}$ \\
\hline \multicolumn{11}{|l|}{ Wife's Age } \\
\hline Less than 25 & 9.8 & \multirow{3}{*}{$34.719^{* * *}$} & 15.6 & \multirow{3}{*}{2.7} & 9.3 & \multirow{3}{*}{4.3} & 3.3 & \multirow{3}{*}{3.2} & 3.2 & \multirow{3}{*}{0.1} \\
\hline $25-40$ & 8.8 & & 18.7 & & 8.6 & & 2.7 & & 3.0 & \\
\hline $40+$ & 6.6 & & 16.2 & & 6.4 & & 0.9 & & 3.2 & \\
\hline \multicolumn{11}{|l|}{ Husband's Age } \\
\hline Less than 25 & 10.9 & \multirow{3}{*}{$46.400^{* * *}$} & 15.7 & \multirow{3}{*}{$8.306^{* *}$} & 8.0 & \multirow{3}{*}{$5.563^{*}$} & 1.6 & \multirow{3}{*}{4.1} & 3.2 & \multirow{3}{*}{0.5} \\
\hline $25-40$ & 9.3 & & 19.5 & & 9.2 & & 3.3 & & 3.2 & \\
\hline $40+$ & 7.3 & & 14.0 & & 6.9 & & 1.7 & & 2.7 & \\
\hline \multicolumn{11}{|l|}{ Place of Residence } \\
\hline Urban & 5.9 & \multirow{2}{*}{$155.298^{* * *}$} & 22.0 & \multirow{2}{*}{$6.035^{* *}$} & 6.8 & \multirow{2}{*}{$6.101^{* *}$} & 2.0 & \multirow{2}{*}{1.7} & 3.7 & \multirow{2}{*}{1.8} \\
\hline Rural & 10.1 & & 16.5 & & 9.2 & & 3.1 & & 2.8 & \\
\hline \multicolumn{11}{|l|}{ Social Status } \\
\hline SC & 11.9 & & 29.2 & & 10.8 & & 3.2 & & 4.3 & \\
\hline ST & 10.5 & $121003 * * *$ & 0 & 521 & 5.9 & $12(57 * * *$ & 0.9 & 7 & 5.9 & $112<$ ж*** \\
\hline OBC & 7.5 & $124.883^{* 2 \pi}$ & 14.9 & $33.164^{\text {sat }}$ & 8.2 & $12.652^{+2 \pi x}$ & 2.7 & 1.7 & 2.3 & $11.264^{+274}$ \\
\hline Others & 7.9 & & 12.8 & & 6.7 & & 2.7 & & 3.1 & \\
\hline Religion & & & & & & & & & & \\
\hline Hindu & 8.4 & & 17.6 & & 8.7 & 4.0 & 2.9 & & 2.7 & \\
\hline Muslim & 12.9 & $103172 * * *$ & 17.2 & 05 & 7.9 & & 1.2 & & 7.5 & $17110 * * *$ \\
\hline Christian & 6.1 & $103.173^{* * *}$ & $\mathrm{NA}$ & 0.5 & 0 & & 2.3 & 2.4 & 3.2 & $17.110^{.7 x}$ \\
\hline Others & 5.7 & & 0.0 & & 0 & & 0 & & $\mathrm{NA}$ & \\
\hline Wealth Quintile & & & & & & & & & & \\
\hline Poorest & 13.3 & & 20.4 & & 10.0 & & 5.5 & & 3.1 & \\
\hline Poor & 12.2 & & 15.8 & & 9.2 & & 3.0 & & 3.8 & \\
\hline Middle & 8.3 & $521.404^{* * *}$ & 17.6 & $13.064^{* *}$ & 9.6 & $20.314^{* * *}$ & 2.9 & $12.415^{* *}$ & 3.1 & 2.3 \\
\hline Richer & 6.6 & & 19.6 & & 7.6 & & 2.4 & & 3.2 & \\
\hline Richest & 3.5 & & 8.8 & & 4.1 & & + & & 2.2 & \\
\hline Wife's Education & & & & & & & & & & \\
\hline No education & 11.4 & & 19.9 & & 9.1 & & 3.7 & & 3.6 & \\
\hline Primary & 8.9 & & 14.1 & & 10.2 & & 2.8 & & 2.7 & \\
\hline Secondary & 6.1 & $350.221^{* * *}$ & 9.4 & $22.377^{* x . x}$ & 7.4 & $19.904^{* \times x}$ & 2.1 & 5.3 & 2.7 & 2.3 \\
\hline Higher & 1.6 & & + & & + & & + & & 1.9 & \\
\hline Husband's Educatio & & & & & & & & & & \\
\hline No education & 12.4 & & 21.6 & & 8.7 & & 3.4 & & 3.8 & \\
\hline Primary & 10.4 & $302184 * * *$ & 14.9 & $19547^{* * *}$ & 10.6 & $15149^{* * *}$ & 3.5 & 32 & 2.8 & 35 \\
\hline Secondary & 7.2 & $302.184^{4+7}$ & 16.3 & $19.34 /+4$ & 8.6 & $15.149^{\prime+1+}$ & 2.2 & 3.2 & 2.9 & 3.5 \\
\hline Higher & 3.9 & & 9.0 & & 4.2 & & 1.8 & & 1.7 & \\
\hline Wife's Exposure to & nedia & & & & & & & & & \\
\hline Yes & 15.7 & $171725 * * *$ & 15.5 & $64155^{* *}$ & 8.5 & 0.0 & 2.5 & 04 & 2.6 & 11 190*** \\
\hline No & 8.6 & $1 / 1.335^{* 7 x}$ & 19.9 & $6.425^{* *}$ & 8.5 & & 3.2 & 0.4 & 5.4 & $11.199^{7.74}$ \\
\hline Husband's Exposure & ass med & & & & & & & & & \\
\hline Yes & 8.3 & $81548 * * * *$ & 16.6 & $8514 * * *$ & 8.5 & 0.1 & 2.6 & 16 & 2.7 & $10030 * * *$ \\
\hline No & 13.3 & $81.548^{7.74}$ & 23.8 & $8.514^{* x \times x}$ & 9.0 & & 4.5 & 1.6 & 7.8 & $19.030^{777}$ \\
\hline Husband drinks Alc & & & & & & & & & & \\
\hline Yes & 10.0 & $41805 * * *$ & 18.4 & & 10.9 & & 4.5 & & 19.1 & \\
\hline No & 7.9 & 41.895 & 17.0 & 0.6 & 7.3 & $15.283^{* *}$ & 1.6 & $13.585^{* \times 7}$ & 17.3 & $10.393^{7 \times 7}$ \\
\hline Total & 8.8 & & 17.6 & & 8.8 & & 2.6 & & 3.1 & \\
\hline Number (n) & 31951 & & 1896 & & 4239 & & 1785 & & 2890 & \\
\hline
\end{tabular}

${ }^{* * *}$ Significant at $1 \%$ Level, ${ }^{* *}$ Significant at $5 \%$ level, ${ }^{*}$ Significant at $10 \%$ Level + Cell frequency less than 5 NA- Not available 


\section{Gap between perception and behavior in the selected districts}

The results of district level analysis showed a little different trend (Table 6). The gap was 20-32 percent in Bellary, Kanpur \& Guntur while in Kishenganj it was 8.2 percent.

More than 32 percent of men in Kanpur had a positive view on the sexual rights of their wives but nevertheless forced them for sex; and 34 percent did not respect wives' decision, thus flouting their own impressive ideology of having positive perception about bodily rights of women. Nearly one-third of men in Bellary, 17 percent in Kishenganj and 14 percent in Guntur did not respect their wife's decision regarding sex, even though they thought that wives had the right to refuse sex.

Table 6: Percentage of Married Men Showing Gap between Perception and Behavior in the Selected Districts

\begin{tabular}{|c|c|c|}
\hline & Forced sex & Respect \\
\hline Districts & $\begin{array}{l}\text { Perception positive still } \\
\text { performed forced sex }\end{array}$ & $\begin{array}{l}\text { Perception positive still did } \\
\text { not respect wife's decision }\end{array}$ \\
\hline Kishanganj (322) & 8.2 & 16.6 \\
\hline Kanpur (322) & 32.5 & 34.2 \\
\hline Bellary (317) & 25.9 & 30.5 \\
\hline Guntur (213) & 19.7 & 14.1 \\
\hline
\end{tabular}

\section{Comparison of Wives' Characteristics among the Negative Disconcordance and Negative Concordance Group}

A close look at men who had a negative perception of women's right found that in many cases such men did not force their wives for sex. Comparisons conducted among the two groups, one where the husbands had perceived negatively and the wives had experienced forced sex (negative concordance) and the other group where husbands had perceived negatively, but whose did not report sexual violence (negative disconcordance). Non-educated women were found to be far less in the negative disconcordance group. There was a high percentage of educated in the negative disconcordance group. The proportion of those below 15 years and who were married was found to be large in this category too. On the other hand, women 
who married at the age group 25 years and above were more in the negative disconcordance group. Though more women in the negative concordance group made decisions on money and health care alone, still, joint decisions by both husband and wife was less in the group and percentages of husbands alone taking a decision was more in this group compared to the negative disconcordance group. Exposure to the media was high among women of negative disconcordance group than women in the other group. These results implied that age at the time of marriage, education, exposure to mass media and decision making power might have empowering role for the lives of women in the negative disconcordance group.

\section{Discussion}

International researchers suggest that a very large proportion of women in developing countries experience sexual assault perpetrated by their partners (Caceres, 2000; Koenig, Zablotska, Lutalo, Nalugoda, Wagman, \& Gray, 2004). Evidence also indicated that substantial sexual coercion against women occurs within marriage. An analysis of over 50 population-based surveys found that approximately 10-50 percent of adult women around the world reported having been physically assaulted by an intimate male partner (including their husbands) at some point in their lives (Jejeebhoy \& Bott, 2005). A study from India, conducted in the states of Gujarat and west Bengal, shows that 12 percent of married young women have experienced unwanted sex frequently and 32 percent of them have experienced sex occasionally. Almost four out of five women say 'no' to their husband when they are unwilling to have sex.

This study found that younger women were more prone to witness sexual violence in marriage. Delayed age at marriage played a prominent role in protecting young women from sexual violence within marriage (Jejeebhoy \& Bott, 2005). Young women in northern states of India were far more likely to experience sexual violence over the course of their married life than their counterparts in Maharashtra and the southern states (Acharya, Ram, jejeebhoy, Singh, Santhya, Ram \& Mohanty, 2009).

Women who justify wife beating, face more sexual violence than those who disagree to the practice. This may be because they rationalize, accept and internalize norms that justify such violence. These issues have also been raised by Santhya, Haberland, Ram, Sinha \& Mohanty (2007) and Wahed \& Bhuiya (2007). In this type of situation, husbands show their sexual prowess and become dominant in relationships which may be the reason these women are sexually abused. 
In terms of the employment status of women, this study's findings are in agreement with Santhya et al., (2007); Acharya et al., (2009) and Acharya, Sabarwal \& Jejeebhoy (2012) who found that working women were at an increased risk of being subjected to forced sex within marriage.

Importantly, the study indicated that wives of alcoholic husbands experienced more sexual violence. This is also supported by numerous studies on the association between alcohol use and sexual violence, where it is found that the likelihood of violence increases with drinking of alcohol (Coleman \& Straus, 1983, Jewkes et al., 2002; Acharya et al., 2009). A study done in lower income areas of greater Mumbai also found that alcohol use by husbands leads from physical and verbal abuse to emotional and sexual violence in marriage (Berg et al., 2010). Forcing wife for sex was also common among the sample of the chosen districts of India. In spite of having positive perception about sexual and reproductive rights of women, a gap prevails between men's perception and actual behaviour. Surprisingly, this gap among men of Kishenganj district was the lowest and could be because large numbers had migrated to other states and even to the Gulf countries. Almost every day many people from Kishanganj in various groups be it children, youth or elderly, migrate to other parts of country or sometimes to abroad in search of job or getting higher and quality education so that they can make a successful career and earn money for livelihood (Alam, 2013). Thus the cultural diffusion effect of migration may have an affection the men in Kishenganj impacting their sexual behaviour and suppressing patriarchal stereotypes.

Interestingly, the study found that sometimes negative perception of men does not reflect in negative behaviour i.e. forcing wives to have sex. Factors like education, mass media exposure, decision making power and increased age at marriage brings a sense of confidence to women; helping them to be conscious of rights (Siddhanta and Singh, 2015).

\section{Conclusions and Recommendations}

Though there prevails strong positive perception among men in India on the bodily rights of women sexual violence is prevalent in regions where there is a large gap between the perception and behavior. This is one of the main reasons why married women face sexual violence. Nearly one in every ten men in India portrayed a gap between perception and behaviour. Ironically, the gap between perception and 
behaviour was highest in Bihar the lowest in Karnataka and Andhra Pradesh implying that men in southern states behaved in the way guided by their positive perception. Wives' age, place of residence, social status, religion, wealth quintile, education, mass media exposure, husband's alcoholism all were significantly associated with the gap between the perception and behaviour of Indian husbands regarding sexual and reproductive rights.

Age at marriage, education, mass media exposure and decision making power may play a protective role in the lives of the women who do not experience sexual violence even when their husband's perception is negative as compared to the women who experience sexual violence under the same condition. The substantial level of nonconsensual sex found in the study suggests inadequacy of sexual and reproductive health programs. The factors that perpetuate men to commit crime, as well as the factors accounting for women's submissive role vis a vis the husband, needs to be identified by policy makers. Positive communication to address power dynamics within marriage needs to be promoted. Improving independent behaviour of the husband is also necessary. A sound and effective support structure that allows women to exercise their reproductive and sexual rights needs to be developed. There is a need for better reproductive and sexual health service for both women and adolescent girls. Education of girls and women should be supported. Evening schools may be conducted for married women, increasing their awareness and strengthening confidence in tacking various issues in their life. Women should also be informed on the consequences of underreporting violence and encouraged to make problems visible.

\section{Acknowledgement}

Authors are thankful to the attendees for their feedback and suggestions on the earlier version of the manuscript which was presented by Ankita Siddhanta at Harvard T.H. Chan School of Public Health, Harvard University, on 22 ${ }^{\text {nd }}$ June 2015. Authors would also like to thank the anonymous reviewers of the JPSS for their helpful comments. 


\section{References}

Acharya, A., Ram, F., Jejeebhoy, S., Singh, A., Santhya, K.G., Ram, U., \& Mohanty, S. (2009). Physical and sexual violence within marriage among youth in India: Findings from the Youth in India, Situation and Needs Study. Paper presented at the XXVI IUSSP International Population Conference, Marrakech, Morocco, 27 September $-2^{\text {nd }}$ October.

Acharya., R., Sabarwal, S, \& Jejeebhoy, S. (2012). Women's empowerment and forced sex within marriage in rural India, Economic and Political Weekly, Vol XL, VII (2), 65-69.

Alam, M. (2013). Mass migration from kishanganj, purnia division and its affects! Time to curtail its rate. Kishenganj Bihar. Com- A gateway to Bihar's heaven. Retrieved from https://kishanganj.blogspot.in/2013/05/mass-migration-fromkishanganj-purnia.html

Barker, G., Contreras, J.M., Heilman, B., Singh, A.K., Verma, R.K., \& Nascimento, M. (2011). Evolving Men: Initial Results from the International Men and Gender Equality Survey (IMAGES). Washington, D.C.: International Center for Research on Women (ICRW) and Rio de Janeiro: Instituto Promundo.

Berg, M. J., Kremelberg, D., Dwivedi, P., Verma, S. Schensul, J. J. J., Gupta, K., Chandran, D. \& Singh, S.K. (2010). The effects of husband's alcohol consumption on married women in three low-income areas of Greater Mumbai. Aids behavior, 14 Suppl 1, S126-135.

Caceres, C., Marin, B., \& Hudes, E. (2000). Sexual coercion among youth and young adults in Lima, Peru, Journal of Adolescent Health, 27, 361-367.

Chadda, S. (2016). Is India a patriarchal society? Youth Survey. Retrieved from http://www.womanendangered.org/india-primarily-patriarchal-society/

Chowdhary, N. \& Patel, V. (2008). The effect of spousal violence on women's health: Findings from the Stree Arogya Shodh in Goa, India. Journal of Postgraduate Medicine, 54, 306-12.

Coleman, D.H., \& Straus, M.A. (1983). Alcohol abuse and family violence. In E. Gottheil, K. A. Druley, T.E., Skoloda, \& H.M. Waxman (Ed.) Alcohol, drug abuse and aggression, Springfield IL: C. Thomas, 104-124.

Gomel, M. K. (1997). A Focus on Women. World Health Organization, Geneva.

Gupta, A., \& Ailawadi, A. (2005). Childhood and adolescent sexual abuse and incest: Experiences of women survivors in India. In Shireen J. Jejeebhoy, Iqbal Shah \&Shyam Thapa (eds) Sex without Consent. New York: Zed books, 171185 . 
Heise, L., Ellsberg, M., \& Goettemoeller, M. (1999). Ending violence against women. Population Reports, 11.

International Institute of Population Sciences \& ICF International. (2016). National Family Health Survey 4: Factsheets. IIPS, Mumbai. Retrieved from http://rchiips.org/NFHS/factsheet_NFHS-4.shtml

International Institute for Population Sciences \& Macro International. (2007). National Family and Health Survey (NFHS-3), India 2005-06, IIPS, Mumbai. International Institute for Population Sciences. (2007-08). CHARCA End Line Survey Report (2007-08), IIPS, Mumbai.

Jejeebhoy, S., \& Bott, S. (2005). Non-consensual sexual experiences of young people in developing countries: An Overview. In Jejeebhoy, S., Shah, I. \& Thapa, S.(Ed.) Sex Without Consent. New York, London: Zed Books, 9-45.

Jewekes, R. (2002). Intimate partner violence: Causes and prevention, Lancet, 359, 1423-1429.

Koenig, M. A., Zablotska, I. B., Lutalo, T., Nalugoda, F., Wagman, J., \& Gray, R. H. (2004a). Coerced first intercourse and reproductive health among adolescent women in Rakai, Uganda. International Family Planning Perspectives, 30(4), 156-164.

Livne, E. (2015). Violence against women in India: Origins, perpetuation and reform (Working Paper, Carneie Mellon University). Pittsburg. Retrieved from http://www.cmu.edu/dietrich/globalstudies/images/livne-gs-capstonepaper.pdf

Miller, B. D. (1993). Sex and Gender Hierarchies. Cambridge: Cambridge UP, Print. National Crime Records Bureau. (2015). Crime in India 2015, Chapter 5: Crime against women. India. Retrieved from http://ncrb.nic.in/StatPublications/CII/CII2015/chapters/Chapter\%20515.11.16.pdf

Renate, K. (2005). Sickening relationship: Gender-based violence, women's health, and the role of informal third parties. Journal of Social and Personal Relationships, 21(1), 146-165.

Santhya, K.G., Haberland, N., Ram, F., Sinha, R.K., \& Mohanty, S.K. (2007). Consent and Coercion: Examining Unwanted Sex among Married Young Women in India. International Family Planning Perspectives, 33(3), 124-132.

Sharma, R. R., Pardasani, R \& Nandram, S. (2014). The problem of rape in India: A multi-dimensional analysis. International Journal of Managing Projects in Business, 7(3), 362-379.

Siddhanta, A. \& Singh, S.K. (2015). Women's background characteristics as protective shield against husband's negative perspective towards sexual and reproductive rights of women. In A Ranjan and B P Singh (Eds.). India 2014: 
Population and Development. Selected papers of Bhopal Seminar 2014. Madhya Pradesh: MLC Foundation and 'Shyam' Institute, 169-178.

Stark, E. \& Flitcraft, A. (1996). Women at risk: domestic violence and women's health. Thousand Oaks, CA: Sage Publications.

Stephenson, R., Koenig, M.A., \& Ahmed, S. (2006). Domestic Violence and Symptoms of Gynecologic Morbidity among Women in North India. International Family Planning Perspectives, 32(4), 201-208.

Wahed, T., \& Bhuiya, A. (2007). Battered bodies \& shattered minds: Violence against women in Bangladesh. Indian Journal of Medical Research, 126, 341354.

Krug, E.G., Dahlberg, L L., Mercy, J A., Zwi, A B., \& Lozano, R. (Eds.). (2002). World report on violence and health. Geneva: World Health Organization. 
Gap between Perception and Bahaviour of Men 